\title{
Bacterial Brown Leaf Spot of Citrus, a New Disease Caused by Burkholderia andropogonis
}

\author{
Y. P. Duan, USDA-ARS-USHRL, Fort Pierce, FL 34945; X. Sun, FDACS-DPI, Gainesville, FL 32610; L. J. Zhou \\ and D. W. Gabriel, Department of Plant Pathology, University of Florida, Gainesville 32610; and L. S. Benyon and \\ Tim Gottwald, USDA-ARS-USHRL, Fort Pierce, FL 34945
}

\begin{abstract}
Duan, Y. P., Sun, X., Zhou, L. J., Gabriel, D. W., Benyon, L. S., and Gottwald, T. 2009. Bacterial brown leaf spot of citrus, a new disease caused by Burkholderia andropogonis. Plant Dis. 93:607-614.

A new bacterial disease of citrus was recently identified in Florida and is here named bacterial brown leaf spot (BBLS) of citrus. BBLS-infected citrus leaves from the field displayed circular, brownish, flat lesions with slightly raised and water-soaked margins surrounded by a chlorotic halo. Based on Biolog carbon source metabolic "fingerprinting", fatty acid analysis, and sequence analysis of partial $16 \mathrm{~S}$ rDNA, gyrB, and $r p o D$ genes, the causal agent of the disease was identified as Burkholderia andropogonis. Pathogenicity of these B. andropogonis isolates taken from multiple citrus leaves with BBLS was tested by various inoculation methods on three species of citrus as well as on carnation, corn, and sorghum. All isolates infected carnation, corn, and sorghum with varying degrees of pathogenicity. Variation among citrus isolates in pathogenicity was also observed in high titer $\left(10^{8} \mathrm{CFU} / \mathrm{ml}\right)$ inoculations of citrus leaves, ranging from a hypersensitive-like response to canker-like lesions. When the inoculum concentration was low $\left(10^{6} \mathrm{CFU} / \mathrm{ml}\right)$, only necrotic spots or small lesions slowly developed with all strains. Growth of B. andropogonis in citrus was relatively slow, tissue wounding appeared necessary for symptom appearance with many isolates, and field samples were recovered only after severe storms, indicating that this wide-host-range bacterium is a weak, opportunistic pathogen of citrus.
\end{abstract}

Burkholderia andropogonis was first described as the causal agent of stripe disease of sorghum and leaf spot of velvet bean in 1911 (20); at that time, it was classified as Pseudomonas andropogonis. Pseudomonas woodsii was also described, in the same publication, as an important pathogen of carnation. These two pathogens were reclassified to the genus Burkholderia based on DNA-rRNA hybridizations (13) and were shown to be synonymous based on phenotypic, genotypic, and chemotaxonomic evidence $(9,13)$. Symptoms of B. andropogonis-infected leaves include brown, water-soaked, circular lesions with chlorotic halos. These lesions can coalesce, resulting in severe blight or leaf drop. When infected leaves are dissected in water, a stream of bacterial ooze is observed. B. andropogonis is now known to cause leaf spot, streaks, and

Corresponding author: Y. P. Duan

E-mail: yongping.duan@ ars.usda.gov

Y. P. Duan and X. Sun contributed equally to this work.

Accepted for publication 3 March 2009.

doi:10.1094/PDIS-93-6-0607

This article is in the public domain and not copyrightable. It may be freely reprinted with customary crediting of the source. The American Phytopathological Society, 2009. stripe on a wide variety of host plants covering 52 species from 15 families of unrelated monocotyledons and dicotyledons, including ornamentals such as white clover, carnation (26), and bougainvillea (29), and economically important crops such as corn, coffee, and chick pea (15). Recent reports show $B$. andropogonis to be a causal agent of diseases of jojoba (10), orchids (23), and golden cane palms (32). It can also survive on weeds such as Johnsongrass and sudangrass (8).

Since 2002, on both residential and commercial citrus plants, citrus leaves with flat, circular, brownish lesions, with slightly raised and water-soaked margins, surrounded by a chlorotic halo have been observed by citrus canker inspectors with the Division of Plant Industry, Florida Department of Agriculture and Consumer Services (DPI-FDAC) (21). The disease was observed only after storms that caused a high degree of damage and wounding to citrus trees. The flat lesions with slightly raised margins appeared somewhat similar to citrus canker (Xanthomonas citri pv. citri) and were therefore sent to the DPIFDAC laboratory for further analysis and identification. However, the lesions were different from those of citrus canker disease, and were confirmed negative for $X$. citri by polymerase chain reaction (PCR) and enzyme-linked immunosorbent assay (ELISA). Under the microscope, a bacterial stream was consistently observed from leaf tissue slices cut from these lesions, and Gram-negative bacteria producing whitish colonies were consistently isolated on nutrient agar plates. All isolates, when inoculated into tomato and pepper, caused hypersensitive reactions (HR), indicating they were likely phytopathogenic. Further testing was conducted to confirm and to characterize the causal agent of what appeared to be a new citrus bacterial disease.

In this paper, we describe bacterial brown leaf spot (BBLS), a new, opportunistic bacterial disease of citrus in Florida, and identify the causal agent to be $B$. andropogonis. Furthermore, we have developed a simple and rapid genetic typing method for differentiating $B$. andropogonis strains using a simple PCR test based on a single primer.

\section{MATERIALS AND METHODS}

Bacterial isolation and pathogenicity tests. Samples were collected from residential and commercial citrus as possible citrus canker lesions from eight counties (Fig. 1A, Table 1). Diseased tissues were surfaced-sterilized and crushed in $1 \mathrm{ml}$ of sterile tap $\mathrm{H}_{2} \mathrm{O}\left(\mathrm{dH}_{2} \mathrm{O}\right)$ in a test tube using a glass rod. Samples were spread on nutrient agar (NA) plates and incubated at $28^{\circ} \mathrm{C}$ for 3 days. Whitish colonies of bacteria producing a diffusible nonfluorescent pigment were consistently isolated. Isolates were purified from single colonies and tested by Gram staining. Isolates were stored at room temperature in sterile tap $\mathrm{H}_{2} \mathrm{O}$ and at $-80^{\circ} \mathrm{C}$ in fresh nutrient broth containing $15 \%$ glycerol. The pathogenicity of all isolates was first screened by infiltrating the bacterial suspension in sterile tap $\mathrm{H}_{2} \mathrm{O}$ at $10^{8} \mathrm{CFU} / \mathrm{ml}$ into leaves of tomato (Lycopersicon esculentum var. esculentum), pepper (Capsicum spp.), and tobacco (Nicotiana tabacum). Isolates producing an HR on tomato and pepper were considered pathogenic. A total of 10 isolates were recovered from infected citrus. For comparison, $B$. andropogonis was isolated from Bougainvillea sp. and from carnation (Dianthus caryophyllus). The $B$. andropogonis type strain (ATCC 23061) from sorghum (renamed 1976 and kindly provided by Jeffery Jones, University of Florida) was also included in many tests (Table 1).

All 12 isolates and the type strain were inoculated into three citrus species: grapefruit (Citrus $\times$ paradisi), key lime (C. au- 
rantiifolia), and sweet orange (C. sinensis). These plants were 2 years of age and had been produced and maintained in greenhouse conditions. Various inoculation methods were evaluated, including spraying with and without wounding, needle puncturing, and pressure infiltrating by tuberculin syringes into newly expanded leaves on new flushes of all three citrus species. The concentration of inocula ranged from $10^{8}$ to $10^{3} \mathrm{CFU} / \mathrm{ml}$ with one $\log$ intervals. The concentrations of $10^{8}$, $10^{7}$, and $10^{6} \mathrm{CFU} / \mathrm{ml}$ were chosen for infiltration studies and for histology. Samples eliciting different symptoms from inoculated citrus were collected, and the inoculated bacteria were reisolated in order to verify that the elicited symptoms were consistent. Inoculation controls included a citrus canker strain (Xanthomonas citri pv. citri), a citrus bacterial spot strain (Xanthomonas axonopodis pv. citrumelo), and sterile tap $\mathrm{H}_{2} \mathrm{O}$. All 10 isolates from citrus were also tested by needle infiltration for their pathogenicity on three known hosts of $B$. andropogonis $(4,18)$ : carnation, corn (Zea mays), and sorghum (Sorghum vulgare), as described by Cother et al. (10).

Histology of lesions. Isolates 6370 and 6367 were inoculated into newly expanded leaves of sweet orange and grapefruit, and samples were collected 2 weeks later at the inoculation site. Multiple samples of $2 \times$ $0.5 \mathrm{~cm}$ leaf tissues containing both healthy and inoculated lesion tissue were sectioned using a razor blade. The sections were placed in vials containing formalin-acidalcohol and fixed for $2 \mathrm{~h}$ under a $500 \mathrm{hPA}$ vacuum in a tissue processor. The sections were dehydrated in a series of alcohol and Histo-Clear baths and then embedded in paraffin. The embedded leaf tissue was cut with a microtome to a thickness of 10 to $15 \mu \mathrm{m}$, floated on warm $\mathrm{H}_{2} \mathrm{O}$, and mounted on Poly-L-Lysine coated microscope slides. The mounted sections were placed on a slide warmer at $42^{\circ} \mathrm{C}$ for $12 \mathrm{~h}$. The paraffin was removed from the tissue sections by placing the microscope slides in Histo-Clear 2 times for $3 \mathrm{~min}$, then rehydrated in 95, 85, 70, 50, and 30\% ETOH 2 times in each solution for 3 min each and a final hydration of $5 \mathrm{~min}$ in $\mathrm{ddH}_{2} \mathrm{O}$. The leaf sections were then stained with Safranin $\mathrm{O}$ for $15 \mathrm{~min}$, and then washed with running $\mathrm{dH}_{2} \mathrm{O}$ until clear. The samples were dehydrated again in a series of alcohol and Histo-Clear baths as described above. A cover glass was then mounted onto the tissue sections with paramount The samples were examined under a microscope and photographed.

In vivo population dynamics. Potted greenhouse-grown grapefruit plants were pruned to produce uniformly aged shoots, and three young shoots were inoculated
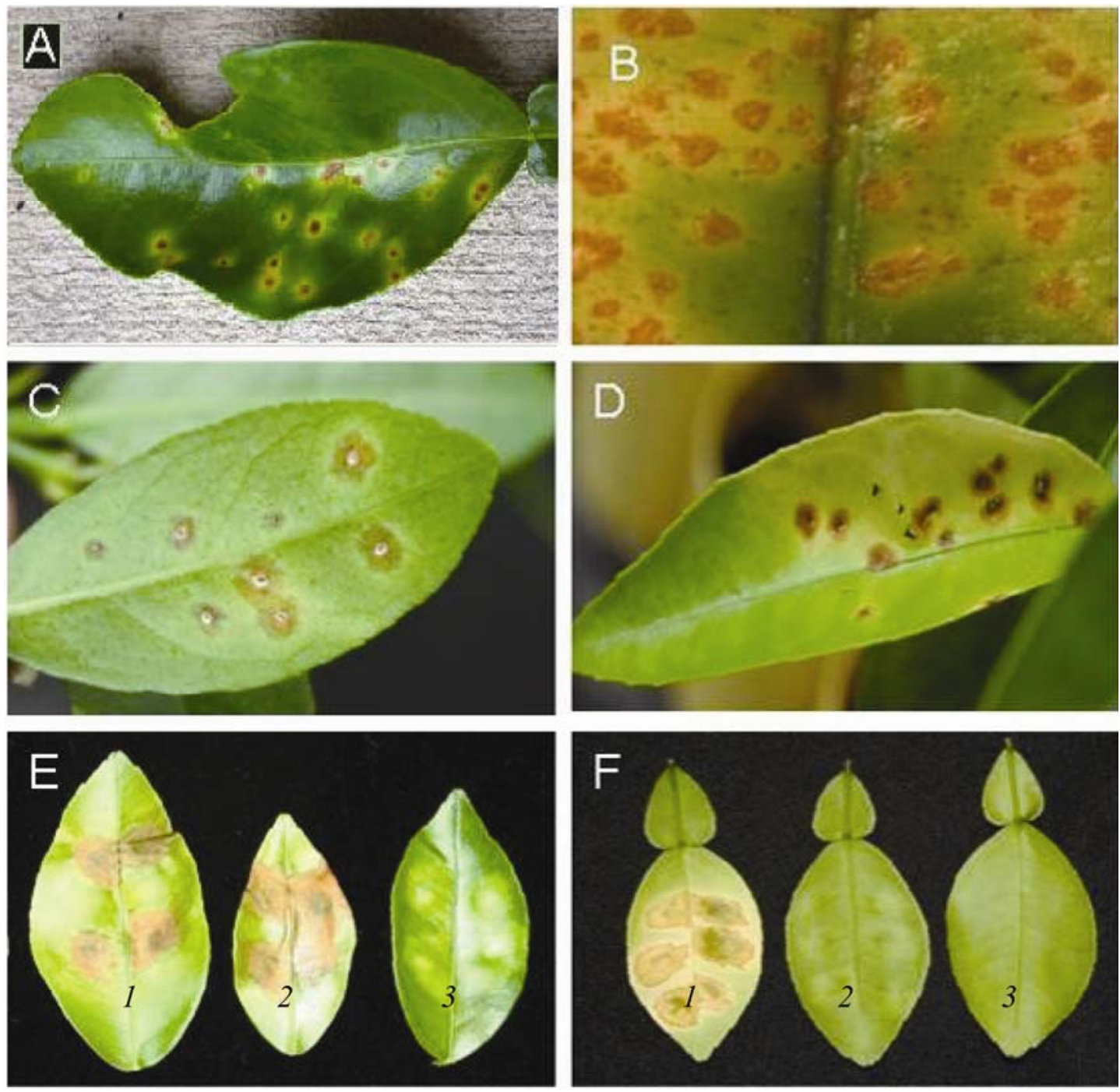

Fig. 1. Field sample and phenotypic variations of citrus leaves inoculated with different isolates of Burkholderia andropogonis. A, Original field sample of bacterial brown leaf spot (BBLS) on grapefruit. B, Grapefruit leaf inoculated with isolate 6269 at concentration $10^{7} \mathrm{CFU} / \mathrm{ml}$ using infiltration. B was photographed 2 weeks after inoculation with $\times 16$ close-up. C, Key lime leaf inoculated with isolate 6269 at concentration $10^{7} \mathrm{CFU} / \mathrm{ml}$ using needle puncture, photographed 3 weeks after inoculation. D, Grapefruit leaf inoculated with isolate 6269 at concentration $10^{7} \mathrm{CFU} / \mathrm{ml}$ using needle puncture, photographed 3 weeks after inoculation. E, Hypersensitive reaction (HR)-like and chlorosis response on grapefruit leaves inoculated with isolate 6177 at $10^{8} \mathrm{CFU} / \mathrm{ml}(1$ and 2) and $10^{6} \mathrm{CFU} / \mathrm{ml}(3)$, respectively, photographed 4 days after inoculation. F, Canker-like lesion on grapefruit inoculated with isolate 6367 at concentration $10^{8} \mathrm{CFU} / \mathrm{ml}$ (1) and $10^{5} \mathrm{CFU} / \mathrm{ml}$ (2), respectively, and healthy control (3), photographed 2 weeks after inoculation. 
per plant. Single colonies from isolates 6269 and 6369 were transferred separately to nutrient broth and grown to log-phase. The cultures were then pelleted by centrifugation, resuspended in sterile tap water, and adjusted to a $10^{4} \mathrm{CFU} / \mathrm{ml}$ culture. The bacterial suspensions were infiltrated into 15 individual leaves on the young grapefruit shoots, using a 1-ml tuberculin syringe and 25 -gauge needle. Inoculated plants were kept in a quarantine greenhouse at 20 to $30^{\circ} \mathrm{C}$. Infiltrated leaves were sampled at $0,2,4,8$, and 12 days after infiltration. At each sample period, two leaf disks (about $1 \mathrm{~cm}^{2}$ total) from infiltrated tissue were triturated in sterile tissue grind- ers containing $1 \mathrm{ml}$ of sterile tap water. The suspension was serially diluted 10 -fold, and $100 \mu \mathrm{l}$ per dilution were spread onto nutrient agar plates. Three infiltrated leaves were used as replications from each time interval. The colonies on each plate were counted after incubation at $28^{\circ} \mathrm{C}$ for $72 \mathrm{~h}$. The experiment was conducted twice.

Carbon utilization and fatty acid analysis. Pure cultures of isolates 6269 and 6369 were grown and tested for utilization of the 95 carbon sources available on GN Microplate (Biolog Inc., Hayward, CA) as previously described (3). The carbon utilization patterns were read with a microplate reader and analyzed by a cluster analysis program provided by Biolog.

Fatty acid profiles were generated for six selected isolates. The bacterial cultures were grown on trypticase soy broth agar (BBL Laboratories, Cockeysville, MD) at $28^{\circ} \mathrm{C}$ for $24 \mathrm{~h}$. Whole-cell fatty acid methyl esters (FAME) were extracted and characterized at the Bacterial Identification and Fatty Acid Analysis Laboratory, Plant Pathology Department, University of Florida, Gainesville. Profiles were pooled and subjected to the Principal Components Analysis using the Microbial Identification System (MIS) software to determine relationships among isolates. The fatty acid

Table 1. Bacterial isolates used in this study

\begin{tabular}{|c|c|c|c|c|}
\hline Strain & Syn. & Species & Origin & Host \\
\hline 1894 & XS2002-0001 & B. andropogonis & Grove, Desoto County & Citrus sp. \\
\hline 6173 & XC2004-00267 & B. andropogonis & Grove, Polk County & C. sinensis \\
\hline 6177 & XI2004-00506 & B. andropogonis & Resident, Lee County & Citrus sp. \\
\hline 6268 & XN2005-1111 & B. andropogonis & Resident, Orange County & C. sinensis \\
\hline 6269 & XI2004-856 & B. andropogonis & Resident, Lee County & Citrus sp. \\
\hline 6367 & XI2005-0014 & B. andropogonis & Resident, Lee County & Citrus sp. \\
\hline 6368 & XC2005-0161 & B. andropogonis & Resident, Indian River County & Citrus $\times$ paradisi \\
\hline 6369 & XC2005-0162 & B. andropogonis & Resident, Indian River County & C. sinensis \\
\hline 6370 & X2005-1008-2 & B. andropogonis & Resident, Palm Beach County & C. reticulata \\
\hline 6758 & XC2005-283 & B. andropogonis & Resident, St Lucie County & C. sinensis \\
\hline 1068 & P1998-2547 & B. andropogonis & Nursery, Marion County & Dianthus caryophyllus \\
\hline 7665 & P2006-15 & B. andropogonis & Resident, Palm Beach County & Bougainvillea sp. \\
\hline 1976 & $\ldots$ & B. andropogonis & ATCC $23061^{\mathrm{a}}$ & Sorghum vulgare \\
\hline D294 & $\ldots$ & B. glumae & Arkansas & Rice \\
\hline D502 & $\ldots$ & B. glumae $^{\mathrm{b}}$ & Arkansas & Rice \\
\hline DNA & $\ldots$ & B. gladioli $^{\mathrm{b}}$ & $\ldots$ & $\ldots$ \\
\hline GMI 1000 & $\ldots$ & Ralstonia solanacearum & Guyana & Tomato \\
\hline 3213 & $\ldots$ & Xanthomonas citri pv. citri & Florida & Citrus \\
\hline 1660 & $\ldots$ & X. citri pv. citri & Florida & Citrus \\
\hline C 340 & & X. citri pv. aurantifolia & ATCC 51302 & Citrus \\
\hline 1377 & $\ldots$ & $X$ axonopodis pv. citrumelo & Florida & Citrus \\
\hline DH $5 \alpha$ & $\ldots$ & Escherichia coli & New England Biolabs & $\ldots$ \\
\hline
\end{tabular}

a Strain provided by Jeffrey B. Jones, University of Florida.

${ }^{\mathrm{b}}$ Strains and DNA provided by Ronald J. Sayler, University of Arkansas.
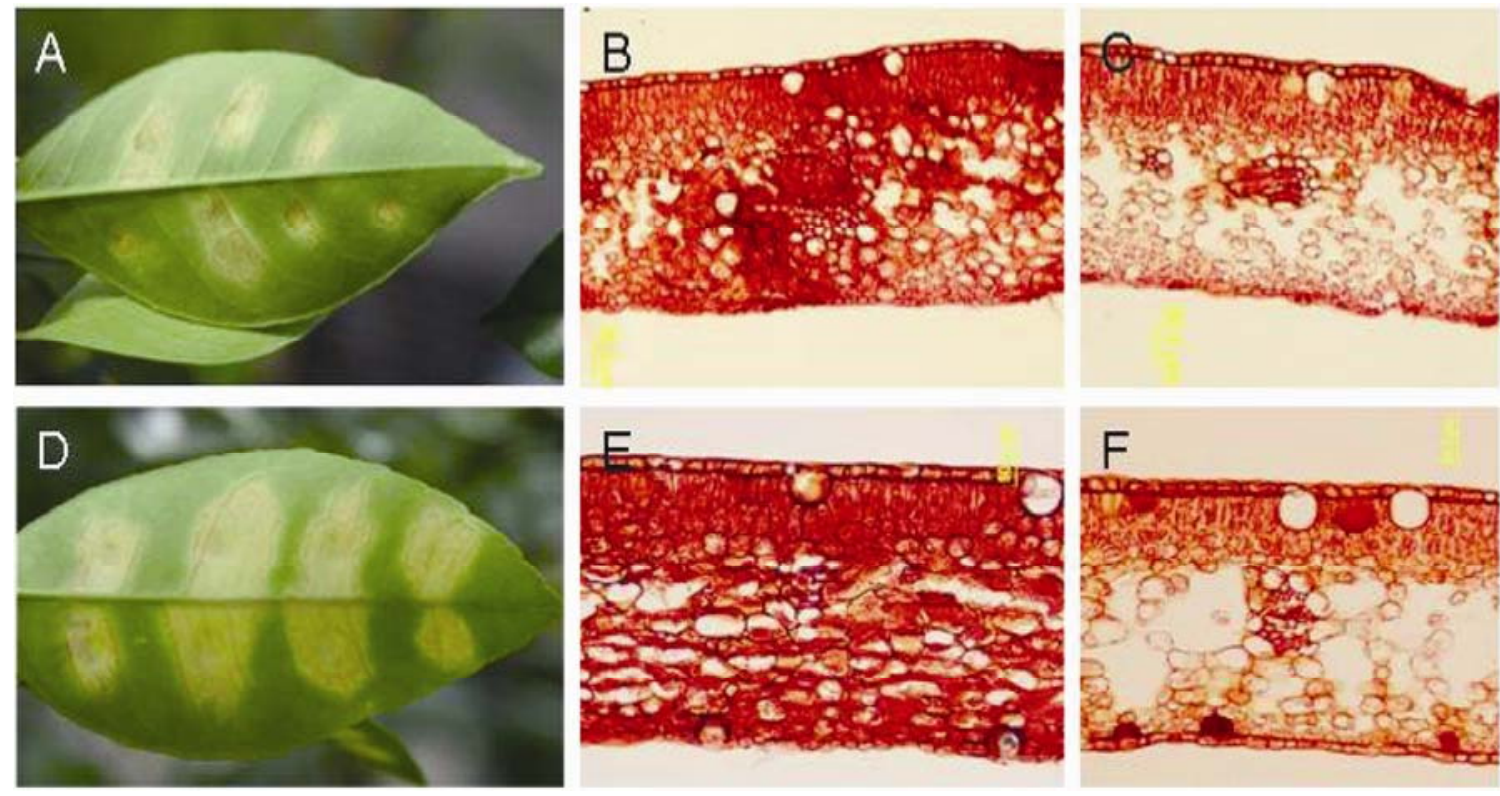

Fig. 2. Lesions induced by Burkholderia andropogonis isolate 6367 and thin-section microscopy of the infected tissue. A, Lesion on sweet orange. B, Thin section of a 2-week-old lesion on sweet orange. Note hypertrophy and absence of hyperplasia. C, Thin section of a healthy control leaf of sweet orange. D, Lesion on grapefruit. E, Thin section of a 2-week-old lesion on grapefruit. Note hypertrophy and absence of hyperplasia. F, Thin section of a healthy control leaf of grapefruit. 
compositions of the isolates were also used to produce an unweighted pair-matching dendrogram based on cluster analysis techniques.

DNA isolation, PCR amplification, and sequence analysis of $16 \mathrm{~S}$ rDNA, gyrB, and $r p o D$. Genomic DNA of all unknown isolates was extracted according to manufacturer's instructions (GenomicPrep Kit, Amersham Pharmacia Biotech, Piscataway, NJ). PCR amplifications of partial $16 \mathrm{~S}$ rDNA, gyrB, and $r p o D$ were performed using primer pairs fD1 and rD1, $\mathrm{LJ} 23 \mathrm{f}$ and $\mathrm{LJ} 24 \mathrm{r}$, and $\mathrm{LJ} 25 \mathrm{f}$ and $\mathrm{LJ} 26 \mathrm{r}$, respectively (Table 2). The PCR reactions were performed using PTC-200 Peltier Thermal Cycler (MJ Research, Inc., Watertown, MA) in a $25-\mu$ l reaction consisting of $1 \times$ buffer D (Epicentre Biotechnologies, Madison, WI) and 1 unit of Taq polymerase (New England BioLabs, Ipswich, MA) under the following conditions: $94^{\circ} \mathrm{C}$ for $2 \mathrm{~min}, 35$ cycles of $94^{\circ} \mathrm{C}$ for $30 \mathrm{~s}, 60^{\circ} \mathrm{C}$ for $30 \mathrm{~s}$, and $72^{\circ} \mathrm{C}$ for $1 \mathrm{~min}$, followed by a final extension cycle of $10 \mathrm{~min}$ at $72^{\circ} \mathrm{C}$. PCR products were purified with a PCR purification kit (QIAquick, Qiagen, Germantown, MD) and were cloned into the pCRII-TOPO cloning vector (Invitrogen, Carlsbad, CA) and identified by direct PCR amplification using M13 forward and reverse primers. The identified clones were grown in LB broth overnight, and DNA was isolated using a plasmid mini kit (Qiagen). DNA sequencing was performed with the BigDye Terminator Cycle Sequencing Kit $\mathrm{v} 3.1$ and M13 universal sequencing primers on the $\mathrm{AB} 3730 \mathrm{xl}$
DNA analyzer (Applied Biosystems, Foster City, CA). Sequences were compared with previously identified sequences in the NCBI database using BLAST (2). The sequences of $16 \mathrm{~S}$ rDNA obtained in this study were aligned with closely matched sequences from the NCBI database using the pileup function of the GCG Package (Accelrys Inc., San Diego, CA) and adjusted manually with ClustalX version 1.8 (24). Phylogenetic trees were generated with Treecon $(27,28)$ using a neighborjoining method. Bootstrap analysis was performed with 1,000 resamplings of the DNA sequences to estimate the confidence of the tree topology.

PCR-based genotyping and sequence analysis of the PCR products. The genetic diversity of citrus isolates was analyzed using a single primer, DG04, which targets an inverted terminal repeat sequence of $X$. citri pv. citri (11). The amplified DNA fragments generated from the PCR reaction were separated on a $1.0 \%$ agarose gel in TAE buffer, and visualized with ethidium bromide staining. PCR products from selected isolates were cloned into the pCRII-TOPO cloning vector and identified by direct PCR amplification using M13 forward and reverse primers. The identified clones were grown in LB broth overnight, and DNA was isolated using a plasmid mini kit (Qiagen). DNA sequencing of the clones was performed by the DNA Sequencing Core Laboratory, Interdisciplinary Center for Biotechnology Research at the University of Florida. Putative functional homologues of the obtained sequences were identified by comparing with previously identified sequences in the NCBI database using BLAST.

\section{RESULTS}

Bacterial isolation and pathogenicity tests. Leaves exhibiting BBLS symptoms were recognized as distinctive from both citrus bacterial spot and Asiatic citrus canker disease (Fig. 1A). The predominant bacterial colonies appearing on nutrient agar plates from ground BBLS leaf samples were whitish and produced a diffusible nonfluorescent pigment. These colonies were consistently isolated from all diseased leaves exhibiting characteristic BBLS symptoms. A total of 10 isolates, one from each of the BBLS field samples of citrus (Table 1), were obtained. The bacteria from these colonies elicited an HR on both tomato and pepper, but not tobacco, when infiltrated into leaves at $10^{9}$ $\mathrm{CFU} / \mathrm{ml}$. All isolates were pathogenic, although in varying degrees, on corn, carnation, and sorghum, causing stripe symptoms on corn and sorghum, and blight symptoms on carnation.

On citrus, the isolates showed significant variation in their pathogenicity and their ability to elicit host responses when using infiltration inoculation (Figs. 1 and 2 , Table 3 ). When a high concentration $\left(10^{8} \mathrm{CFU} / \mathrm{ml}\right)$ of isolates 6177,6758 , and 1894 were infiltrated into newly expanded citrus leaves, an HR-like symptom was elicited (Fig. 1E). This HR-like symptom was readily apparent at approximately $48 \mathrm{~h}$ after inoculation, and abscission of inoculated leaves occurred 24 to $48 \mathrm{~h}$ later. In contrast, the HR elicited by $X$. citri pv. citri strain $\mathrm{A}^{\mathrm{W}}$ and $X$. citri pv. aurantifolia strain $\mathrm{C}$ on grapefruit appeared at least 72 $\mathrm{h}$ after inoculation, and the rapid abscission of inoculated leaves was not observed (data not shown). When the inoculum was diluted 100 -fold to $10^{6} \mathrm{CFU} / \mathrm{ml}$, these isolates caused either chlorosis or no obvious symptoms (Fig. 1E). Isolates 6268, 6269 , and 6370, when infiltrated at high

\begin{tabular}{llll}
\multicolumn{4}{l}{ Table 2. Polymerase chain reaction $(\mathrm{PCR})$ and sequencing primers used in this study } \\
\hline Primer & Target gene & Sequence $\left(\mathbf{5}^{\prime} \mathbf{-} \mathbf{3}^{\prime}\right)$ & Reference \\
\hline fD1 & 16S rDNA & AGAGTTTGATCCTGGCTCAG & 30 \\
rD1 & & AAGGAGGTGATCCAGCC & 30 \\
LJ23f & gyrB & GGGGGTGTCTTGCGTAAAC & This study \\
LJ24r & & ACACCAGCTTGTCCTTCGTCT & This study \\
LJ25f & $r p o D$ & CGCCAAACGGATCGAGGAAGG & This study \\
LJ26r & & TCACCCAGCGGCAACACGAC & This study \\
DG04 & Invert repeats & AAT CCC TGC CGA CCC TC & 11 \\
\hline
\end{tabular}

Table 3. Pathogenicity tests on sweet orange, key lime, and grapefruit and selected known hosts of Burkholderia andropogonis following high level leaf tissue infiltration inoculation with bacterial brown leaf spot (BBLS) isolates and selected strains of B. andropogonis

\begin{tabular}{|c|c|c|c|c|c|c|c|c|}
\hline \multirow[b]{2}{*}{ Isolate/strain } & \multirow[b]{2}{*}{ Sweet orange } & \multicolumn{2}{|c|}{ Key lime } & \multicolumn{2}{|c|}{ Grapefruit } & \multirow[b]{2}{*}{ Carnation $^{\mathrm{a}}$} & \multirow[b]{2}{*}{ Corn $^{a}$} & \multirow[b]{2}{*}{ Sorghum $^{\mathrm{a}}$} \\
\hline & & Infiltration & Needle-puncture & Infiltration & Needle-puncture & & & \\
\hline 6173 & $\mathrm{Ch}+{ }^{\mathrm{b}}$ & $\mathrm{Ch}++$ & + & $\mathrm{Ch}++$ & + & +++ & +++ & + \\
\hline 6177 & HR+++ & HR+++ & \pm & HR+++ & \pm & + & + & + \\
\hline 6268 & $\mathrm{Ch}++$ & HR+++ & ++ & $\mathrm{C}++$ & ++ & ++ & ++ & +++ \\
\hline 6269 & $\mathrm{Ch}++$ & $\mathrm{C}++$ & ++ & $\mathrm{C}++$ & ++ & + & ++ & + \\
\hline 6367 & $\mathrm{C}+++$ & $\mathrm{C}++$ & ++ & $\mathrm{C}++$ & ++ & +++ & +++ & +++ \\
\hline 6368 & HR+++ & HR+++ & + & $\mathrm{Ch}++$ & + & +++ & +++ & + \\
\hline 6369 & HR++ & HR++ & + & $\mathrm{C}++$ & + & ++ & ++ & ++ \\
\hline 6370 & $\mathrm{Ch}++$ & $\mathrm{HR}++$ & ++ & $\mathrm{C}++$ & ++ & ++ & ++ & + \\
\hline 6758 & HR+++ & HR+++ & + & HR+++ & + & +++ & ++ & +++ \\
\hline 1894 & $\mathrm{HR}+++$ & $\mathrm{HR}+++$ & + & $\mathrm{HR}+++$ & + & ++ & +++ & +++ \\
\hline 1068 & $\mathrm{HR}+++$ & $\mathrm{HR}++$ & + & $\mathrm{Ch}++$ & + & +++ & +++ & + \\
\hline 1976 & $\mathrm{Ch}++$ & $\mathrm{Ch}+$ & \pm & $\mathrm{HR}+++$ & \pm & +++ & +++ & +++ \\
\hline 7665 & $\mathrm{HR}+++$ & $\mathrm{HR}+++$ & \pm & $\mathrm{Ch}+$ & \pm & +++ & +++ & ++ \\
\hline
\end{tabular}

a Symptoms scored after 2 weeks.

${ }^{\mathrm{b}} \mathrm{Ch}=$ Chlorosis (after 2 weeks); HR = hypersensitive-like response (after 2 days); C = Canker-like lesions (after 2 weeks). +, ++, +++ represents apparent intensity of response. 
levels, caused raised lesions similar to citrus canker disease after 1 to 2 weeks, but only on grapefruit; on sweet orange and key lime, only small, flat lesions with raised margins appeared after 2 weeks. Following low level infiltration, lesions elicited by these strains appeared after 1 month (i.e., small canker-like lesions on grapefruit and small flat lesions with raised margins on sweet orange and key lime). Isolate 6367 caused canker-like lesions (Fig. 2A and D) on all three species of citrus tested after 1 to 2 weeks following high level inoculations, and small cankerlike lesions on all three species after 2 to 4 weeks at low level inoculations.

Spraying of a low concentration $\left(10^{6}\right.$ $\mathrm{CFU} / \mathrm{ml}$ ) of any of these BBLS isolates on nonwounded citrus leaves resulted in no lesions. In contrast, all isolates at a low concentration caused lesions (Fig. 1C and D) on citrus with needle-puncture inoculation; however, the resulting lesions were of varied sizes and required longer than a month to develop. Wounding of citrus tissue therefore appeared to be critical for lesion development from low level inoculations.

Histology of $B$. andropogonis lesions. Isolates of $B$. andropogonis from BBLS citrus caused raised, necrotic, and cankerlike lesions when the bacteria were inoculated into newly expanded citrus leaves. Thin-section microscopy of infected grapefruit and sweet orange tissues revealed an increase in the volume of mesophyll cells (i.e., hypertrophy) and the loss of free extracellular space in the apoplast in the raised lesion area (Fig. 2). In contrast to citrus canker disease, no hyperplasia was observed.

In vivo growth dynamics. Growth kinetic studies revealed the bacterium grew relatively slowly inside citrus leaf tissue. According to the growth curves produced for the two isolates, 6269 and 6369, the populations exhibited less than two-log growth over a 12-day period and achieved only a low overall titer in citrus, less than $10^{4} \mathrm{CFU} / \mathrm{cm}^{2}$ (Fig. 3).

Identification of the causal agents of BBLS. All 10 citrus BBLS isolates were Gram-negative. Isolates 6269 and 6369 were identified as $B$. andropogonis using carbon utilization profiles. Isolates 6268 , 6269, 6367, 6368, 6369, and 6370 were identified as $B$. andropogonis using FAME analysis, and their index values varied from 0.692 to 0.934 . The dendrogram produced based on fatty acid composition showed that these six isolates formed a cluster with $B$. andropogonis, separate from B. glumae and B. gladioli. They appear to be the same species (Fig. 4).

Uniform DNA fragments of ca. 1,500 bp were amplified by PCR using universal 16S rDNA primers; no polymorphism was observed following restriction enzyme digestion using HhaI and TagI (data not shown). The $16 \mathrm{~S}$ rDNA sequences from all isolates and the type strain were obtained.
Isolates 1068 (accession no. FJ387578), 1894 (FJ387579), 1976 (FJ387580), 6173 (FJ387581), 6177 (FJ595135), 6268 (FJ387582), 6269 (DQ786950), 6367 (FJ387583), 6368 (FJ387584), 6369 (DQ786951), 6370 (FJ387585), 6758 (FJ387586), 6893 (FJ387587), and 7665 (FJ387588) shared more than 99\% identities with the previously reported $B$. andropogonis 16S rDNA gene sequences in the NCBI database. The phylogenetic placement and relationship of the representative BBLS isolates to other closely related plant pathogenic bacteria using 16S rDNA sequences is illustrated in Figure 5. The results of the 16S rDNA sequence analysis confirmed the identification of the citrus BBLS isolates as B. andropogonis.
In addition, uniform DNA fragments amplified by PCR using gyrB and $r p o D$ were obtained, cloned, and sequenced. All sequences from $g y r B$ and $r p o D$ also shared over $99 \%$ identities with the previously reported $B$. andropogonis gyrB and $r p o D$ sequences, respectively, in the NCBI database (Table 4). The results of the sequence analysis of these two house-keeping genes, gyrB and $r p o D$, further confirmed the identification of the citrus BBLS isolates as $B$. andropogonis. Primers designed for gyr $B$ were specific for PCR detection of $B$. andropogonis among the tested bacterial samples (Fig. 6).

Genetic diversity of citrus isolates analysis by PCR. Differing patterns of $\mathrm{PCR}$ products were observed among $B$.

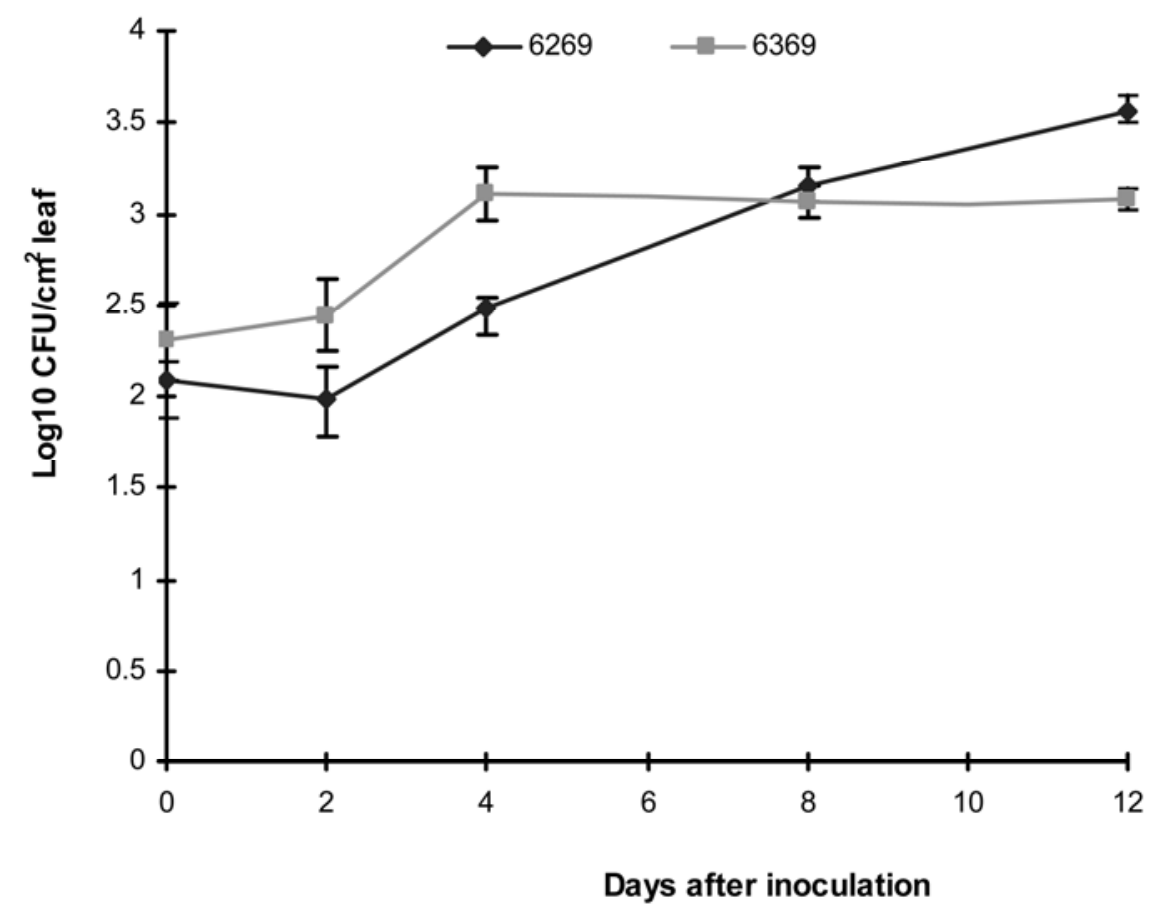

Fig. 3. Population dynamics of Burkholderia andropogonis isolates 6269 and 6369 in grapefruit (Citrus $\times$ paradisi $)$. Data are means of three replications repeated twice $(n=6) \pm$ standard error of the mean.

Burkholderia gladioli

B. glumae (ATCC 49703A)

B. andropogonis

B. andropogonis (6369)

B. andropogonis (6368)

B. andropogonis (6370)

B. andropogonis (6269)

B. andropogonis (6367)

B. andropogonis (6268)
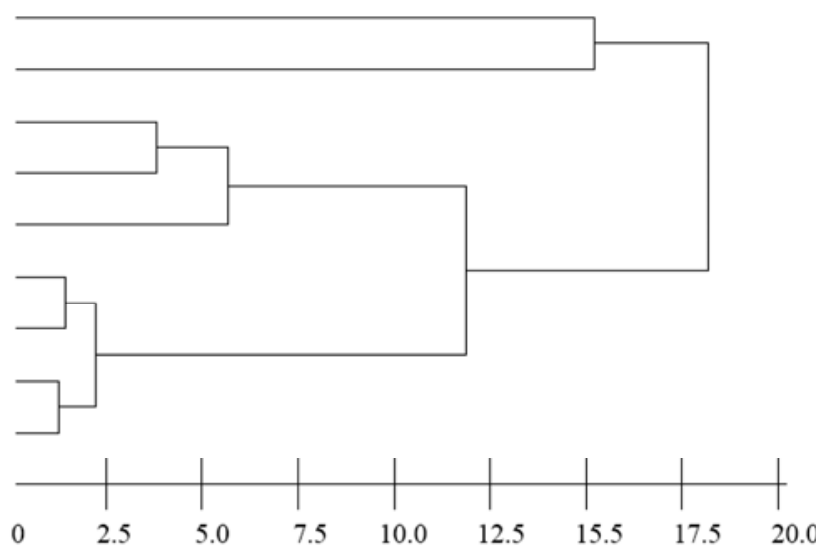

Euclidian Distance

Fig. 4. Dendrogram showing the relationships of Burkholderia andropogonis strains isolated from citrus and other Burkholderia species based on the fatty acid analysis. 
andropogonis citrus isolates using the inverted repeat sequence-based primer DG04. Four of the 10 citrus isolates examined $(6268,6269,6367$, and 6370) shared a similar pattern of two PCR products (Fig. 7). Sequence analysis of the DNA fragments of one of the four isolates, 6269, revealed the presence of a phage integraselike protein composed of 261 amino acids (EU346201) in the large fragment, and presence of an $\mathrm{ABC}$ transporter-like protein composed of 131 amino acids
(EU346202) in the small fragment. Isolate 6177 displayed a unique PCR amplification pattern, and the amplicon was identified as a putative iron-sulfur-binding reductase-like protein (EU909698). The PCR products of primer DG04 revealed different genetic elements, indicating a degree of genetic diversity among the isolates.

\section{DISCUSSION}

This is the first report of bacterial brown leaf spot (BBLS) of citrus, a new and ap- parently opportunistic bacterial disease of citrus. Typical symptoms of the disease are flat, circular, brownish lesions with slightly raised and water-soaked margins surrounded by a chlorotic halo. The occurrence of the disease in the field was consistently associated with storms that caused damage to citrus, indicating the bacteria infected citrus plants via wounds. By fulfilling Koch's postulates and discerning that the causal agent was indeed a bacterium, we eliminated other diseases of cit-

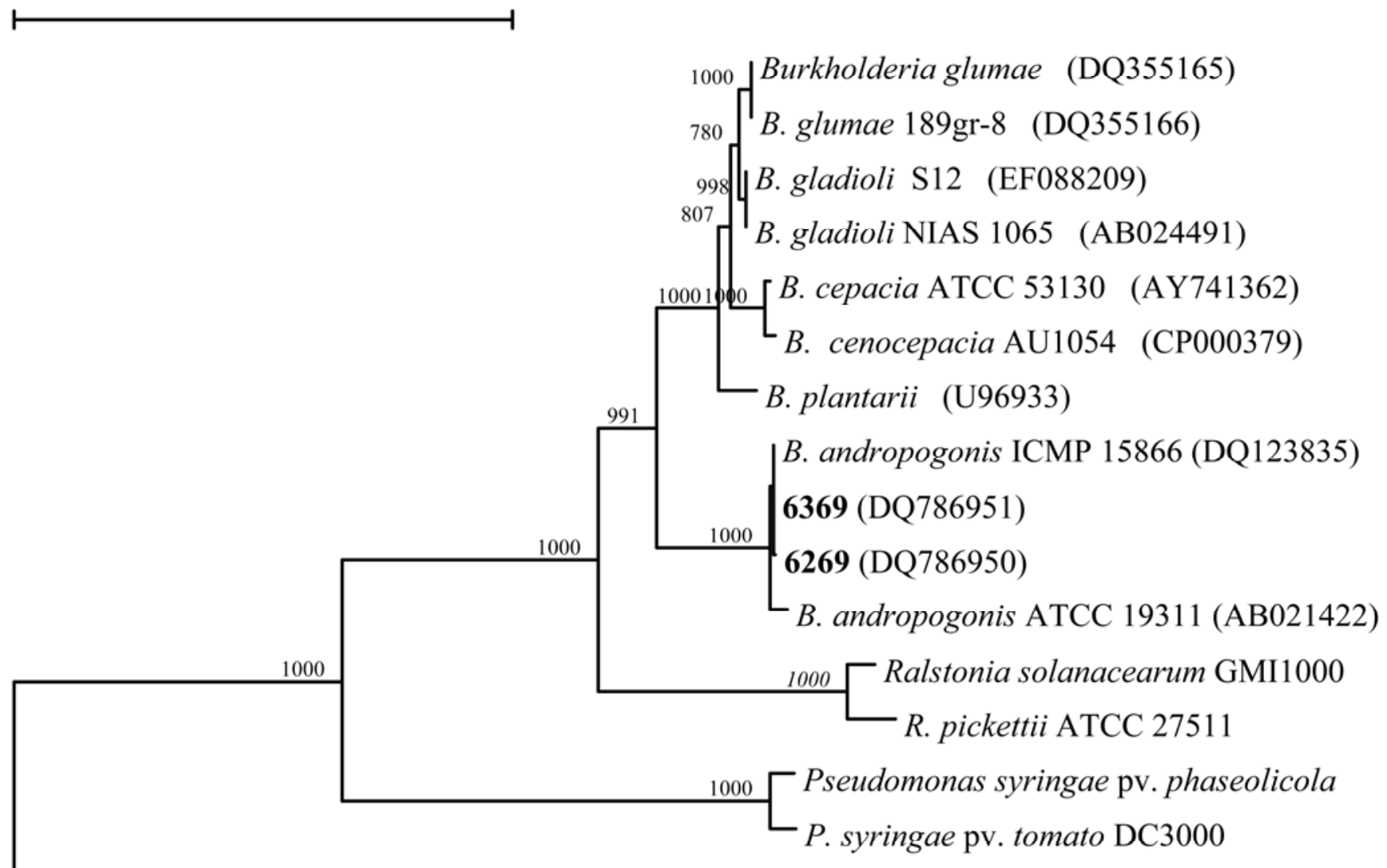

\section{Agrobacterium tumefaciens}

Fig. 5. Neighbor-joining phylogenetic placement of Burkholderia andropogonis and related plant pathogens. Analysis based on approximately 1,500-nt sequences from positions 27-1543 (based on Escherichia coli numbering) of 16S rDNA with Agrobacterium tumefaciens as the outgroup taxon. Scale bar represents $10 \%$ change. Numbers at nodes represent percentage of bootstrap resampling based on 1,000 replicates.

Table 4. Comparison of fatty acid analysis and $g y r B, r p o D$ gene sequence analyses results for identification of Burkholderia andropogonis isolates

\begin{tabular}{|c|c|c|c|c|c|c|c|c|}
\hline \multirow[b]{2}{*}{ Isolate/strain } & \multirow[b]{2}{*}{ Biolog I.D. } & \multirow{2}{*}{$\begin{array}{l}\text { Fatty acid } \\
\text { sim index }\end{array}$} & \multicolumn{3}{|c|}{$\operatorname{gyrB}$ BLAST $^{\mathrm{b}}$} & \multicolumn{3}{|c|}{ rpoD BLAST ${ }^{b}$} \\
\hline & & & Score & E-value & Acc. num. & Score & E-value & Acc. num. \\
\hline 6173 & N/A & N/A & 1279 & 0.0 & EU265649 & 1369 & 0.0 & EU306162 \\
\hline 6177 & N/A & N/A & 1279 & 0.0 & EU265650 & 1369 & 0.0 & EU306163 \\
\hline 6268 & N/A & 0.739 & 1279 & 0.0 & EU265651 & 1369 & 0.0 & EU306164 \\
\hline 6269 & B. andropogonis & 0.696 & 1279 & 0.0 & EU265652 & 1369 & 0.0 & EU265662 \\
\hline 6367 & N/A & 0.692 & 1279 & 0.0 & EU265653 & 1369 & 0.0 & EU306165 \\
\hline 6368 & N/A & 0.908 & 1279 & 0.0 & EU265654 & 1369 & 0.0 & EU306166 \\
\hline 6369 & B. andropogonis & 0.934 & 1284 & 0.0 & EU265655 & 1369 & 0.0 & EU306167 \\
\hline 6370 & N/A & 0.734 & 1279 & 0.0 & EU265656 & 1369 & 0.0 & EU306168 \\
\hline 6758 & N/A & N/A & 1279 & 0.0 & EU265657 & 1363 & 0.0 & EU306169 \\
\hline 1894 & N/A & N/A & 1279 & 0.0 & EU265658 & 1369 & 0.0 & EU306170 \\
\hline 1068 & N/A & N/A & 1279 & 0.0 & EU265659 & 1369 & 0.0 & EU306171 \\
\hline 1976 & N/A & N/A & 1279 & 0.0 & EU265660 & 1369 & 0.0 & EU306172 \\
\hline 7665 & N/A & N/A & 1279 & 0.0 & EU265661 & 1369 & 0.0 & EU306173 \\
\hline
\end{tabular}

${ }^{a}$ A similarity index of fatty acid greater than 0.8 is considered an exact match.

${ }^{\mathrm{b}}$ All BLAST score values represent the highest match to B. andropogonis gyrB (GenBank accession no. AB190572) and rpoD (GenBank accession no. AB190669). 
rus which display similar phenotypes. These included the fungal diseases: greasy spot (Mycosphaerella citri) (31), Phaeoramularia fruit and leaf spot (Pseudocercospora angolensis), and Alternaria brown spot (Alternaria citri) $(7,25)$.

The bacteria only caused lesions when they were inoculated by needle puncture or infiltration but not by spraying without wounding, confirming the field observation that the bacteria infected plant tissues via wounds. A growth dynamics study revealed that the multiplication of BBLS isolates from citrus was slow, increasing less than two logs in 12 days (Fig. 3). When compared to a four-log increase in 8 days of $X$. citri pv. citri (21), this study indicates that the BBLS isolates are poor pathogens of citrus and supports the opportunistic nature of BBLS field infections. Based on the results of Biolog metabolic profiles, FAME analysis, and sequence analysis of $16 \mathrm{~S}$ rDNA, gyrB, and $r p o D$ genes, the causal agent of the bacterial brown leaf spot disease of citrus was identified as Burkholderia andropogonis. This eliminated other bacterial diseases that cause lesions: citrus bacterial spot (CBS; $X$. axonopodis pv. citrumello) and citrus canker $(X$. citri) $(12,19)$. The necessity of wounding for infection by $B$. andropogonis has been observed in other host plants, including Limonium sinuatum, Bougainvillea spectabilis, Coffea arabica (17), and carnation (6).

Unlike in B. glumae and B. gladioli (16), sequence analysis of the gyrB and $r p o D$ genes did not differentiate among the BBLS isolates; all of them share more than 99\% identities, even those that elicited different host responses. However, cellular fatty acid composition indices of the BBLS isolates ranged from 0.692 to 0.934 . The same variation has also been reported in $B$. andropogonis strains isolated from jojoba, where the similarity index ranged from 0.342 to 0.829 (10). Furthermore, when using the DG04 primer, which was designed for genetic typing of $X$. citri (citrus canker) strains (11) based on the terminal inverted repeat sequences that flank the pathogenicity gene $p t h A$ (22), we obtained different PCR products from these isolates (Fig. 7). Four of the 11 isolates examined shared a similar pattern of PCR products using DG04, and these same isolates/strains were found to be more pathogenic to citrus.

B. andropogonis infects a wide variety of host plants and causes leaf spot, streaks, stripe, and blight on unrelated monocotyledons and dicotyledons $(10,17,23,29,32)$. Leaf lesions on these plants vary in their color, including tan, purple, brown, and black, with variations occurring not just between the hosts but among hosts. Symptoms on carob, Ceratonia siliqua L., have been described as dark tan to black lesions, irregular in shape, with a paler green margin (17). The symptom variation also includes the lesion size as in jojoba, Simmondsia chinensis, where lesions are described as ranging from "necrotic flecking" with water-soaked halos to larger "eyespots" (10). $B$. andropogonis, along with B. glumae and $B$. plantarii, produces non-host-specific toxins that induce chlorosis or necrosis of plant tissue (14). It is intriguing that when infiltrated at high concentrations, some of the BBLS isolates induced a rapid HR-like response in citrus. Unlike $X$. citri pv. citri $\mathrm{A}^{\mathrm{W}}$ and $X$. citri pv. aurantifolia strain $\mathrm{C}(1)$, the HR-like responses induced by the BBLS isolates were more rapid and were not citrus host specific. Furthermore, no hypersensitive response and pathogenicity ( $h r p)$ genes, necessary to produce an $\mathrm{HR}$, have been reported in B. andropogonis. On the other hand, the culture filtrates of these isolates from nutrient broth did not exhibit any toxic effects on citrus (data not shown). Whether the HR-like phenotype induced by the BBLS isolates is controlled by Type III effector genes, toxins, or some other mechanism entirely remains to be investigated.

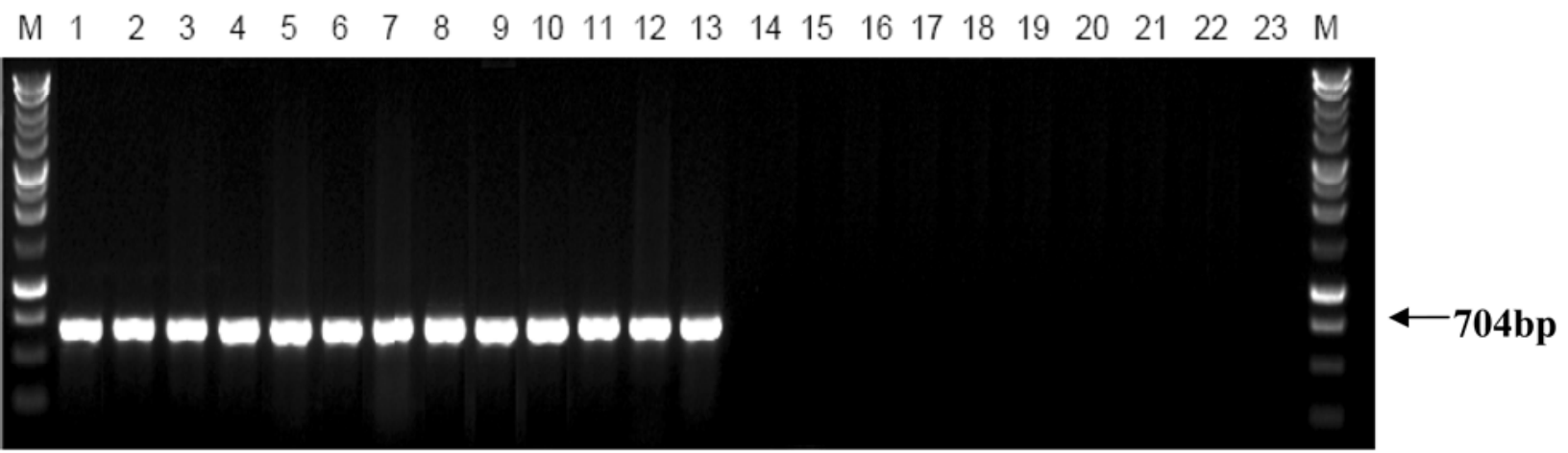

Fig. 6. Polymerase chain reaction (PCR) test for the specificity of primer LJ23f/LJ24r designed from Burkholderia andropogonis gyrB gene. Lane M, 1-kb DNA ladder; lanes 1-13, B. andropogonis 6173, 6177, 6268, 6269, 6367, 6368, 6369, 6370, 6758, 1068, 1894, ATCC23061, 7665; lane 14, Xanthomonas axonopodis pv. citri 3213; lane 15, X. axonopodis pv. citri 1660; lane 16, X. axonopodis pv. citrumelo 1377; lanes 17-18, Burkholderia glumae D294, D502; lanes 19-20, Burkholderia sp.; lane 21, Escherichia coli DH5a; lane 22, Ralstonia solanacearum GMI 1000; lane 23, water control.

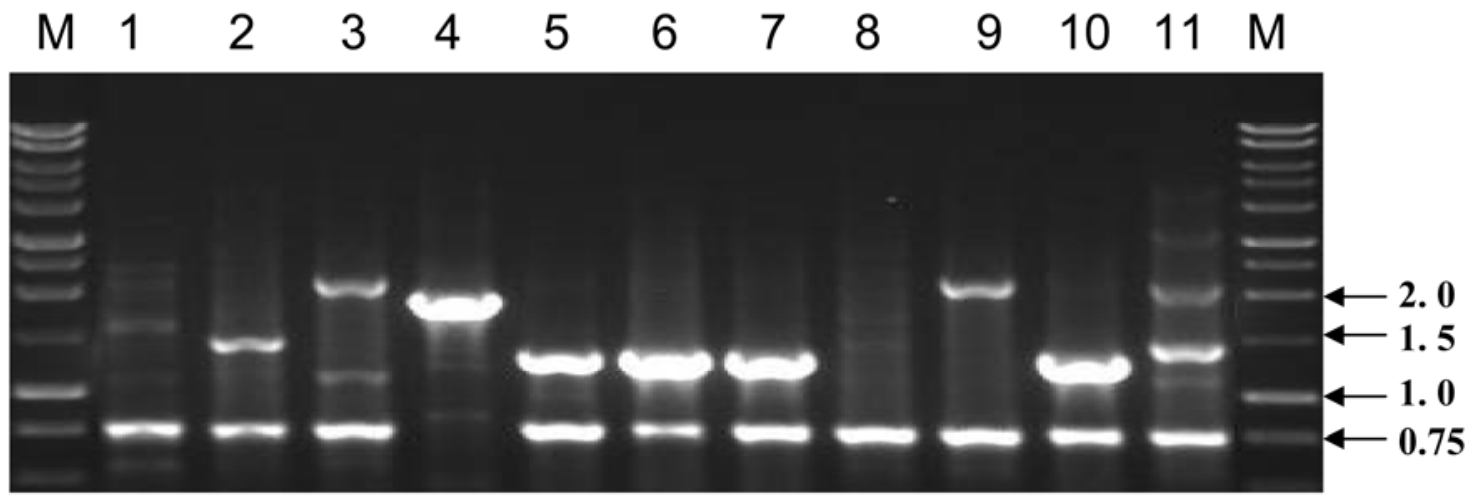

Fig. 7. Genetic diversity analysis of Burkholderia andropogonis isolates using polymerase chain reaction (PCR) amplification with DG04 primer. M, 1-kb DNA marker (Promega, Madison, WI). Lanes 1-11, B. andropogonis isolates 1068, 1976, 6173, 6177, 6268, 6269, 6367, 6368, 6369, 6370, and 7665, respectively. 
BBLS was discovered because these isolates were submitted by state inspectors as citrus canker suspects. Thus, the lesions of BBLS obviously can be confused with those of citrus canker. Typical canker symptoms include raised, erumpent lesions with a water-soaked margin, and are histologically characterized by both hypertrophy and hyperplasia (5). BBLS elicits small lesions that are flat with slightly raised margins. Microscopically, B. andropogonis causes hypertrophy but does not induce hyperplasia. The causal agent of citrus bacterial spot, $X$. axonopodis pv. citrumello, also causes flat, water-soaked leaf spots on juvenile citrus $(12,22)$, but this nursery disease does not affect mature trees. Although there are some symptom similarities among these bacterial diseases, BBLS lesions can be distinguished by a reddish appearance on grapefruit (Fig. 1A) and sweet orange. Since BBLS lesions on citrus can be confused with atypical lesions of citrus canker, it is important for inspectors and growers to be informed regarding this new bacterial disease of citrus in order to limit confusion. Also due to the difficulty in differentiating BBLS from atypical citrus canker and bacterial spot by symptomology, serological and molecular tools are necessary to aid in diagnosis. The primers DG04 and those that target the $g y r B$ and $r p o D$ genes of $B$. andropogonis developed from this study may be used for future PCR detection and diagnosis.

\section{ACKNOWLEDGMENTS}

We are thankful to Debbie Jones and Lisa Jones, Florida Department of Agriculture and Consumer Services, Division of Plant Industry, and Kimberly Poole, USDA-ARS-USHRL, for their excellent technical support in this research.

\section{LITERATURE CITED}

1. Al-Saadi, A., Reddy, J. D., Duan, Y. P., Brunings, A. M., Yuan, Q. P., and Gabriel, D. W. 2007. All five host-range variants of Xanthomonas citri carry one pthA homolog with 17.5 repeats that determines pathogenicity on citrus, but none determine host-range variation. Mol. Plant-Microbe Interact. 20:934-943.

2. Altschul, S. F., Gish, W., Miller, W., Myers, E. W., and Lipman, D. J. 1990. Basic local alignment search tool. J. Mol. Biol. 215:403410.

3. Bouzar, H., Jones, J. B., and Hodge, N. C. 1993. Differential characterization of Agrobacterium species using carbon-source utilization patterns and fatty acid profiles. Phytopathology 83:733-739.

4. Bradbury, J. 1986. Guide to Plant Pathogenic Bacteria. CABI Publishing, Wallingford, UK.

5. Brunings, A. M., and Gabriel, D. W. 2003. Xanthomonas citri: Breaking the surface. Mol. Plant Pathol. 4:141-157.

6. Burkholder, W. H., and Guterman, C. E. F. 1935. Bacterial leaf spot of carnations. Phytopathology 25:114-120.
7. Chung, K. R., and Timmer, L. W. 2007. Citrus diseases exotic to Florida: Phaeoramularia fruit and leaf spot (PFLS). Plant Pathology Department, Florida Cooperative Extension Service, Institute of Food and Agricultural Science, University of Florida, Gainsville.

8. Claflin, L. 2000. Diseases caused by prokaryotes. Pages 5-7 in: Compendium of Sorghum Diseases, 2nd ed. American Phytopathological Society, St. Paul, MN.

9. Coenye, T., Laevens, S., Gillis, M., and Vandamme, P. 2001. Genotypic and chemotaxonomic evidence for the reclassification of Pseudomonas woodsii (Smith 1911) Stevens 1925 as Burkholderia andropogonis (Smith 1911) Gillis et al. 1995. Int. J. Syst. Evol. Micr. 51:183-185.

10. Cother, E. J., Noble, D., Peters, B. J., Albiston, A., and Ash, G. J. 2004. A new bacterial disease of jojoba (Simmondsia chinensis) caused by Burkholderia andropogonis. Plant Pathol. 53:129-135.

11. Duan, Y., Gabriel, D. W., Sutton, B., Sun, X., Schulbert, T., and Dixon, W. 2006. Rapid genetic typing of citrus canker strains found in Florida. Page 125 in: Proc. 11th Int. Conf. Plant Pathogenic Bacteria, Edinburgh, Scotland.

12. Gabriel, D. W., Kingsley, M. T., Hunter, J. E., and Gottwald, T. 1989. Reinstatement of Xanthomonas-Citri (Ex Hasse) and XanthomonasPhaseoli (Ex Smith) to Species and Reclassification of All Xanthomonas-Campestris Pv Citri Strains. Int. J. Syst. Bacteriol. 39:14-22.

13. Gillis, M., Vanvan, T., Bardin, R., Goor, M., Hebbar, P., Willems, A., Segers, P., Kersters, K., Heulin, T., and Fernandez, M. P. 1995. Polyphasic taxonomy in the genus Burkholderia leading to an emended description of the genus and proposition of Burkholderia vietnamiensis sp-nov for $\mathrm{N}_{2}-$ fixing isolates from rice in Vietnam. Int. J. Syst. Bacteriol. 45:274-289.

14. Gonzalez, C. F., Venturi, V., and Engledow, A. 2007. The phytopathogenic Burkholderia. Pages 153-176 in: Burkholderia: Molecular microbiology and genomics. T. Coenye and P. Vandamme, eds. Horizon Bioscience, Norfolk, UK.

15. Hayward, A. C. 1983. Pseudomonas: The nonfluorescent pseudomonads. Pages 107-140 in: Plant Bacterial Diseases: A Diagnostic Guide. P. C. Fahy and G. J. Persley, eds. Academic Press, Sydney, Australia.

16. Maeda, Y., Shinohara, H., Kiba, A., Ohnishi, K., Furuya, N., Kawamura, Y., Ezaki, T., Vandamme, P., Tsushima, S., and Hikichi, Y. 2006. Phylogenetic study and multiplex PCR-based detection of Burkholderia plantarii, Burkholderia glumae and Burkholderia gladioli using gyrB and $r p o D$ sequences. Int. J. Syst. Evol. Micr. 56:1031-1038.

17. Moffett, M. L., Hayward, A. C., and Fahy, P. C. 1986. Five new hosts of Pseudomonas andropogonis occurring in eastern Australia: Host range and characterization of isolates. Plant Pathol. 35:34-43.

18. Ramundo, B. A., and Claflin, L. E. 2005. Identification of Burkholderia andropogonis with a repetitive sequence BOX element and PCR. Curr. Microbiol. 50:52-56.

19. Schaad, N. W., Postnikova, E., Lacy, G. H., Sechler, A., Agarkova, I., Stromberg, P. E., Stromberg, V. K., and Vidaver, A. K. 2005. Reclassification of Xanthomonas campestris pv. citri (ex Hasse 1915) Dye 1978 forms A,
$\mathrm{B} / \mathrm{C} / \mathrm{D}$, and $\mathrm{E}$ as $X$. smithii subsp citri (ex Hasse) sp nov nom. rev. comb. nov., $X$. fuscans subsp aurantifolii (ex Gabriel 1989) sp nov nom. rev. comb. nov., and $X$. alfalfae subsp citrumelo (ex Riker and Jones) Gabriel et al., 1989 sp nov nom. rev. comb. nov.; X. campestris pv malvacearum (ex Smith 1901) Dye 1978 as X. smithii subsp smithii nov comb. nov nom. nov.; X. campestris pv. alfalfae (ex Riker and Jones, 1935) Dye 1978 as X. alfalfae subsp alfalfae (ex Riker et al., 1935) sp nov nom. rev.; and "var. fuscans" of $X$. campestris pv. phaseoli (ex Smith, 1987) Dye 1978 as X. fuscans subsp fuscans sp nov. Syst. Appl. Microbiol. 28:494-518.

20. Smith, E. F. 1911. Bacteria in relation to plant diseases. Carnegie Institute Publications, Washington, DC, USA

21. Sun, X., Duan, Y. P., Jones, D. D., Schubert, T. S., Dickstein, E. R., and Stall, R. E. 2006. Determination of an opportunistic bacterial pathogen on citrus in Florida. Page 144 in: Proc. 11th Int. Conf. Plant Pathogenic Bacteria, Edinburgh, Scotland.

22. Swarup, S., Yang, Y. N., Kingsley, M. T., and Gabriel, D. W. 1992. An Xanthomonas citri pathogenicity gene, PthA, pleiotropically encodes gratuitous avirulence on nonhosts. Mol. Plant-Microbe Interact. 5:204-213.

23. Takahashi, Y., Takahashi, K., Watanabe, K., and Kawano, T. 2004. Bacterial black spot caused by Burkholderia andropogonis on Odontoglossum and intergeneric hybrid orchids. J. Gen. Plant Pathol. 70:284-287.

24. Thompson, J. D., Gibson, T. J., Plewniak, F., Jeanmougin, F., and Higgins, D. G. 1997. The CLUSTAL_X windows interface: Flexible strategies for multiple sequence alignment aided by quality analysis tools. Nucleic Acids Res. 25:4876-4882.

25. Timmer, L. W., Roberts, P. D., Chung, K. R., and Bhatia, A. 2008. Alternaria Brown Spot. Plant Pathology Department, Florida Cooperative Extension Service, Institute of Food and Agricultural Science, University of Florida, Gainsville.

26. Trujillo, E. E., and Nagata, N. M. 1994. Bacterial blight of carnation caused by Pseudomonas woodsii and susceptibility of carnation cultivars. Plant Dis 78:91-94.

27. Van de Peer, Y., and De Wachter, R. 1994 TREECON for Windows: A software package for the construction and drawing of evolutionary trees for the Microsoft Windows environment. Comput. Appl. Biol. Sci. 10:569-5710.

28. Van de Peer, Y., and De Wachter, R. 1997. Construction of evolutionary distance trees with TREECON for Windows: Accounting for variation in nucleotide substitution rate among sites. Comput. Appl. Biol. Sci. 13:227-230.

29. Walker, S. E., and Hodge, N. C. 1991. Bacterial leaf spot of Bougainvillea in Florida caused by Pseudomonas andropogonis. Plant Dis. 75:968.

30. Weisburg, W. G., Barns, S. M., Pelletier, D. A., and Lane, D. J. 1991. 16s ribosomal DNA amplification for phylogenetic study. J. Bacteriol. 173:697-703.

31. Whitesid, Jo. 1970. Etiology and epidemiology of citrus greasy spot. Phytopathology 60:14091414.

32. Young, A. J., Grice, K. R. E., Trevorrow, P. R., and Vawdrey, L. L. 2007. Burkholderia andropogonis blight of golden cane palms in north Queensland. Australas. Plant Dis. Notes 2:131132. 